\title{
Pengaruh Intensif, Tingkat Pendidikan, Pelatihan dan Pengalaman Kerja Pada Kinerja Individu Pengguna Sistem Informasi Akuntansi
}

\author{
Putu Dhana Belawa ${ }^{1}$ \\ I Made Pande Dwiana Putra ${ }^{2}$
}

\author{
${ }^{1}$ Fakultas Ekonomi dan Bisnis Universitas Udayana (Unud), Bali, Indonesia \\ e-mail : abelawa94@gmail.com/ Tlp:081999001799 \\ ${ }^{2}$ Fakultas Ekonomi dan Bisnis Universitas Udayana (Unud), Bali, Indonesia
}

\begin{abstract}
ABSTRAK
Dinas perindustrian dan perdagangan Kota Denpasar dalam mendukung dan menjalankan kegiatannya membutuhkan kinerja individu yang memadai terkait penggunaan sistem informasi akuntansi. Tujuan dari penelitian ini adalah menganalisis pengaruh intensif, tingkat pendidikan, pelatihan dan pengalaman kerja pada kinerja individu pengguna sistem informasi akuntansi di Disperindag Kota Denpasar. Penelitian ini dilakukan di kantor Dinas Perindustrian dan Perdagangan Kota Denpasar tahun 2017 dengan menjadikan seluruh karyawan pengguna sistem informasi akuntansi yang bekerja pada Disperindag Kota Denpasar yaitu sebanyak 60 orang karyawan sebagai sampel dengan metode sensus. Pengumpulan data dilakukan dengan wawancara, menyebarkan kuesioner, dan teknik analisis menggunakan regresi linear berganda. Berdasarkan hasil analisis, diketahui bahwa intensif, tingkat pendidikan, pelatihan dan pengalaman kerja berpengaruh positif terhadap kinerja individu pengguna sistem informasi akuntansi di Disperindag Kota Denpasar.

Kata kunci : intensif, tingkat pendidikan, pelatihan, pengalaman kerja, kinerja individu sistem informasi akuntansi
\end{abstract}

\begin{abstract}
Denpasar Industry and Trade Office in supporting and carrying out its activities requires adequate individual performance related to the use of accounting information system. This study aimed to determine the effect of incentives, level of education, training and work experience on the performance of individual user of acccounting information system unit in industry and trade office Denpasar city. This study was conducted at Denpasar Industry and Trade Office in 2017 by making all employees of accounting information system users who work at Disperindag Denpasar City as many as 60 employees as a sample with census method. The data were collected by interviewing, distributing questionnaires, and analysis techniques using multiple linear regression. Based on the results of the analysis, it is known that intensive, level of educations, training and work experience positively affect the individual performance of accounting information system users in industry and trade ofice of Denpasar City.

Keywords : icentives, level of educations, training, work experience, performance of individual user of accounting informations system
\end{abstract}

\section{PENDAHULUAN}

Perkembangan teknologi yang semakin melanda dunia mempunyai dampak yang cukup besar bagi lembaga-lembaga pemerintahan. Hal tersebut tentunya menjadi suatu tantangan bagi pimpinan suatu lembaga pemerintahan untuk menciptakan 
terobosan baru dan mulai mengembangkan metode dan aplikasi baru untuk mengatasi kendala-kendala di masa mendatang (Diah dan Dharmadiaksa, 2013). Kemampuan mengatasi permasalahan atau kendala tersebut memerlukan strategi yang dapat memanfaatkan semua kekuatan dan peluang yang ada, serta meminimalkan kelemahan dan menetralisasi hambatan yang dihadapi. Semua itu dapat dilakukan apabila pimpinan suatu lembaga mampu melakukan pengambilan keputusan yang didasarkan pada informasi yang berkualitas. Informasi yang berkualitas akan terbentuk dari adanya sistem informasi yang dirancang baik (Windha et al., 2013).

Sistem informasi pemerintahan di Indonesia telah tumbuh pesat. Pemerintahan merupakan salah satu penyedia jasa bagi masyarakat baik dalam bentuk SKPD (satuan kerja perangkat daerah) untuk setiap Kabupaten/Kota, sedangkan dalam bentuk biro untuk setingkat Provinsi. Tantangan penggunaan sistem informasi pada bidang pemerintahapun menjadi semakin ketat (Ika dan Vika, 2016). Menurut Davis dan Venkatesh (2000) rendahnya penggunaan sistem informasi diidentifikasikan sebagai penyebab utama yang mendasari terjadinya productifity paradox yaitu investasi yang mahal di bidang sistem tetapi menghasilkan tingkat pengembalian yang rendah.

Productifity paradox, di antara isu manajemen yang mengemuka saat ini, terkait pencarian sumber dana non-konvensional dan efisiensi, termasuk pemanfaatan teknologi informasi. Dalam literatur tercatat juga bahwa telah banyak usaha perusahaan untuk merespon secara aktif perubahan tersebut, termasuk dengan menerapkan reorganisasi melalui business process 
reengineering (BPR) yang salah satunya menggunakan teknologi informasi (TI). Tidak sedikit perusahaan yang mengalami kegagalan dalam implementasi teknologi informasi (TI). Investasi-invetasi di bidang TI seringkali tidak diikuti dengan hasil yang maksimal bagi perusahaan, baik dari sisi produktivitas, profitabilitas maupun nilai yang akan diterima oleh suatu entitas bisnis. Inilah yang menyebabkan fenomena "productivity paradox", di mana investasi yang besar tidak menghasilkan manfaat yang besar juga (Davis dan Venkatesh, 2000).

Secara administratif Denpasar mempunyai fungsi ganda, yaitu sebagai ibu Kota Denpasar dan ibu Kota Provinsi Bali. Denpasar juga merupakan pusat berbagai kegiatan, yaitu pusat pemerintahan, perdagangan, perekonomian, dan pendidikan. Pembangunan Kota Denpasar yang berkesinambungan membutuhkan pendapatan dan kemampuan daerah yang terus meningkat (Diah dan Dharmadiaksa, 2013). Dalam mendukung pembangunan daerah, diperlukan suatu sistem informasi yang baik serta meningkatkan kinerja dari sumber daya manusianya (Moses, 2015).

Insentif merupakan salah satu faktor yang berpengaruh terhadap kinerja pengguna sistem informasi akuntansi (Siti et al., 2015). Salah satu cara untuk meningkatkan kinerja individu seseorang adalah dengan pemberian insentif bagi pegawai yang melaksanakan tugasnya dengan baik. Salah satu faktor dalam meningkatkan kinerja individu adalah pemberian insentif sebagai bentuk balas jasa yang sesuai dengan tanggung jawab pekerjaan yang telah dilakukan mereka kepada perusahaan (Diah dan Dharmadiaksa, 2013). Ika dan Vika (2016) menyatakan insentif dapat dirumuskan sebagai balas jasa yang memadai kepada 
pegawai yang prestasinya melebihi standar yang telah ditetapkan. Adapun bentuk insentif adalah gaji, tunjangan, bonus, dan komisi.

Peranan insentif diharapkan dapat merangsang disiplin kerja karyawan, sehingga akan meningkatkan produktivitas dan tujuan suatu lembaga dapat diwujudkan. Menurut Gorda (2006:144), pemberian insentif oleh suatu lembaga akan dapat membangun, memelihara dan memperkuat harapan karyawan, sehingga dalam diri mereka timbul disiplin kerja yang tinggi dan konsisten dalam berprestasi. Diah dan Dharmadiaksa (2013) dalam penelitiannya menyatakan bahwa pemberian insentif pada pegawai memberikan pengaruh positif terhadap kinerja individu pengguna sistem informasi akuntansi. Begitupun dengan David et al. (2012) dalam penelitiannya membuktikan bahwa insentif merupakan salah satu faktor yang berpengaruh positif terhadap kinerja individu pengguna sistem informasi akuntansi. Lain halnya dengan Siti et al. (2015) dalam penelitiannya menemukan insentif tidak memiliki pengaruh terhadap kinerja audit dengan efektivitas sistem informasi akuntansi. Rohida et al. (2016) menyatakan insentif memiliki pengaruh tidak signifikan terhadap kinerja pengelola keuangan sistem informasi akuntansi.

Lebih lanjut faktor-faktor yang juga perlu diperhatikan untuk meningkatkan kinerja individu seseorang adalah tingkat pendidikan karyawan yang berbeda sehingga baik itu pendidikan formal maupun non formal misalnya pendidikan dari tingkat Sekolah Dasar (SD) hingga Sarjana (S1), sehingga pada saat pengambilan keputusan menjadi tepat dan akurat (Diah dan Dharmadiaksa, 2013). Pendidikan dan pelatihan merupakan unsur yang penting dalam mendukung kinerja individu 
(Anugraheni, 2014). Notoatmodjo (2009:17), pendidikan pada umumnya berkaitan dengan mempersiapkan calon tenaga yang diperlukan oleh suatu instansi atau organisasi yang lebih menitik beratkan pada pengembangan kemampuan umum, sedangkan pelatihan lebih berkaitan dengan peningkatan kemampuan atau keterampilan karyawan yang sudah menduduki suatu pekerjaan atau tugas tertentu sehingga penekakanannya pada tugas yang harus dilaksanakan. Pendidikan dan pelatihan yang diadakan oleh Disperindag Kota Denpasar berupa pembentukan, penjenjangan, dan penunjang. Masing-masing tahapan tersebut terdiri dari berbagi kegiatan untuk meningkatkan kemampuan teknis, teoritis, konseptual, moral pegawai supaya memiliki kinerja yang baik, dan mencapai hasil yang optimal (Rohida et al, 2016). Tiksnayana dan Maria (2016) dalam penelitiannya menemukan pendidikan secara parsial tidak memiliki pengaruh terhadap efektivitas penggunaan sistem informasi akuntansi. Rosiana (2010) menyatakan pendidikan secara parsial tidak berpengaruh terhadap kinerja efektivitas sistem informasi akuntansi.

Memberikan pelatihan khusus sangat berguna bagi karyawan yang berpengalaman dan juga untuk karyawan yang belum berpengalaman sesuai bidangnya (Tiksnayana dan Maria, 2016). Ardana dkk. (2012:91) menyatakan bahwa pelatihan ini dilaksanakan untuk karyawan baru agar dapat menjalankan tugas-tugas baru yang dibebankan dan untuk karyawan lama guna meningkatkan mutu pelaksanaan tugasnya sekarang maupun di masa datang yang pada dasarnya merupakan proses yang berlanjut dan bukan proses sesaat saja. Melalui prosesproses tersebut, karyawan diharapkan akan lebih memaksimalkan tanggung jawab 
atas pekerjaan mereka karena telah terbekali oleh pelatihan yang tentu berkaitan dengan implementasi kerja mereka (Abdol et al, 2013).

Rohida et al. (2016) dalam penelitiannya menyatakan bahwa pendidikan yang dimiliki pegawai memberikan pengaruh positif terhadap kinerja individu pengguna sistem informasi akuntansi. Hal yang sama dibuktikan oleh Tiksnayana dan Maria (2016), bahwa pendidikan yang dimiliki pegawai berpengaruh positif terhadap kinerja individu pengguna sistem informasi akuntansi. Lain halnya Ika dan Vika (2016) dalam penelitiannya menemukan pelatihan secara parsial tidak memiliki pengaruh terhadap efektivitas penggunaan sistem informasi akuntansi. Diah dan Dharmadiaksa (2013) menyatakan pelatihan secara parsial tidak berpengaruh terhadap kinerja efektivitas sistem informasi akuntansi.

Menurut Simamora (2007:287), pelatihan adalah serangkaian aktivitas yang dirancang untuk meningkatkan keahlian-keahlian, pengetahuan, pengalaman ataupun perubahan sikap individu. Mathis and Jackson (2006:5) menambahkan pelatihan adalah proses di mana orang-orang mencapai kemampuan tertentu untuk membantu mencapai tujuan organisasi. Program pelatihan yang diberikan secara terus-menerus bertujuan untuk meningkatkan pengetahuan, kemampuan penguasaan teknologi, dan mempelajari keterampilan-keterampilan baru sehingga para karyawan mampu bekerja dengan baik. Ika dan Vika (2016) dalam penelitiannya menyatakan bahwa pelatihan yang diberikan kepada pegawai memberikan pengaruh positif terhadap kinerja individu pengguna sistem informasi akuntansi. Hal yang sama dibuktikan oleh Tiksnayana dan Maria (2016) dalam penelitiannya membuktikan bahwa pelatihan yang diberikan terhadap 
pegawai berpengaruh positif terhadap kinerja individu pengguna sistem informasi akuntansi.

Pengalaman berpengaruh terhadap kinerja individu pengguna sistem informasi akuntansi karena pengalaman merupakan salah satu hal penting dalam pengambilan suatu keputusan. Semakin lama seseorang bekerja, maka pengalaman kerja serta pengetahuan yang dimiliki akan semakin bertambah (Windha et al., 2013). Sebaliknya, semakin singkat masa kerja seseorang biasanya semakin sedikit pula pengalaman serta pengetahuan yang diperoleh (Ezeani dan Ogbonna, 2012). F Red and D. Avis (2006) dalam penelitiannya menyatakan bahwa pengalaman yang dimiliki pegawai memberikan pengaruh positif terhadap kinerja individu pengguna sistem informasi akuntansi. Kondisi yang sama dibuktikan oleh Tiksnayana dan Maria (2016) yang dalam penelitiannya membuktikan bahwa pengalaman seorang pegawai berpengaruh positif terhadap kinerja individu pengguna sistem informasi akuntansi. Krisnawati (2009) dalam penelitiannya menemukan pengalaman kerja tidak memiliki pengaruh terhadap kinerja efektivitas sistem informasi akuntansi. Rohida et al. (2016) menyatakan pengalaman kerja tidak berpengaruh terhadap kinerja pengelola keuangan sistem informasi akuntansi.

Pengalaman seseorang sangat mempengaruhi kinerja suatu individu karena semakin lama pengalaman kerja yang dimiliki maka seseorang akan memiliki tingkat keahlian yang baik dalam bidangnya (Tiksnayana dan Maria, 2016). Nomza (2015) menyatakan pengalaman kerja merupakan suatu proses atau tingkat penguasaan pengetahuan serta keterampilan seseorang dalam pekerjaannya yang 
Putu Dhana Belawa dan I Made Pande Dwiana Putra. Pengaruh ...

dapat diukur dari masa kerja, tingkat pengetahuan dan keterampilan yang dimilikinya. Manulang (2007:25) mengatakan pengalaman kerja adalah proses pembentukan pengetahuan atau keterampilan tentang metode suatu pekerjaan karena keterlibatan karyawan tersebut dalam pelaksanaan tugas pekerjaan. Monica dan Lorenzo, (2012) mengatakan pengalaman kerja adalah pengetahuan atau keterampilan yang telah diketahui dan dikuasai seseorang akibat dari perbuatan atau pekerjaan yang telah dilakukan selama beberapa waktu tertentu. Tiksnayana dan Maria (2016) mendapatkan hasil pengalaman kerja berpengaruh positif terhadap efektivitas sistem informasi akuntansi.

Akuntansi pada hakikatnya merupakan suatu proses yang dapat menghasilkan informasi yang digunakan manajer untuk menjalankan operasi perusahaan. Akuntansi merupakan suatu sistem informasi (P. Patel, 2015). Sistem informasi akan memberikan kemudahaan bagi para akuntan manajemen untuk menghasilkan informasi keuangan yang dapat dipercaya, relevan dan tepat waktu dapat dipahami dan teruji sehingga akan membantu pengambilan keputusan (Jaluanto dan Nerile, 2014).

Handoko (2007:112), menyatakan sistem informasi merupakan suatu sistem yang tujuannya menghasilkan informasi. Dalam melaksanakan kegiatan operasi lembaga pemerintahan, diperlukan adanya pimpinan yang baik dengan ditunjang oleh personil yang berkualitas agar dapat berkarya secara efisien. Sumber daya manusia dalam suatu lembaga adalah faktor dominan dalam pencapaian suatu tujuan, karena tanpa pertimbangan faktor perilaku manusia, sistem yang dirancang tidak akan dapat berjalan dengan baik. Salah satu perilaku manusia yang menjadi 
perhatian paling utama di lembaga pemerintahan yaitu kesalahan-kesalahan dalam menggunakan sistem informasi akuntansi yang sehingga mengakibatkan sistem informasi akuntansi menjadi tidak efektif (Agus dan Shofi, 2014).

Berdasarkan uraian di atas, maka dapat dilihat bahwa pemberian insentif, tingkat pendidikan, pelatihan dan pendidikan diduga berpengaruh terhadap kinerja individu pengguna sistem informasi akuntansi di Disperindag Pemerintah Kota Denpasar. Tujuan dari penelitian ini Berdasarkan perumusan masalah yang telah disebutkan sebelumnya adalah sebagai berikut: 1). Untuk mengetahui pengaruh insentif terhadap kinerja individu pengguna sistem informasi akuntasi pada Disperindag Kota Denpasar, 2). Untuk mengetahui pengaruh tingkat pendidikan terhadap kinerja individu pengguna sistem informasi akuntansi pada Disperindag Kota Denpasar, 3). Untuk mengetahui pengaruh pelatihan terhadap kinerja individu pengguna sistem informasi akuntansi pada Disperindag Kota Denpasar, 4). Untuk mengetahui pengaruh pengalaman kerja terhadap kinerja individu pengguna sistem informasi akuntansi pada Disperindag Kota Denpasar.

Catherine and Bernard (2012) menyatakan bahwa Theory of Reasoned Action (TRA) atau teori tindakan bersama atau sering dikenal dengan teori tindakan beralasan yang dikembangkan oleh Ajen dan Fishbein (1980). TRA adalah suatu teori yang berhubungan dengan sikap dan perilaku individu dalam melaksanakan kegiatan. Secara singkat, praktik atau perilaku TRA dipengaruhi oleh niat, sedangkan niat dipengaruhi oleh sikap dan norma subyektif. Secara lebih sederhana, teori ini mengatakan bahwa seseorang akan melakukan suatu 
Putu Dhana Belawa dan I Made Pande Dwiana Putra. Pengaruh ...

perbuatan apabila mereka memandang perbuatan itu positif (Diah dan Dharmadiaksa, 2013).

Mc Queen and Mills (2008) mengatakan bahwa secara keseluruhan perilaku seseorang dapat dijelaskan dengan mempertimbangkan kepercayaannya, karena kepercayaan seseorang mewakili informasi yang mereka peroleh tentang dirinya sendiri dan dunia di sekitarnya. Sarah et al. (2002) berpendapat bahwa dengan reaksi dan persepsi seseorang terhadap sesuatu hal, akan menentukan sikap dan perilaku orang tersebut. Teori ini membuat model perilaku seseorang sebagai suatu fungsi dari tujuan perilaku. Brigitte and Wolfgang (2013) menyatakan bahwa TRA merupakan tahapan manusia melakukan suatu tindakan. Pada tahap awal, perilaku (behavior) diasumsikan ditentukan oleh niat (intention) seseorang yang digunakan untuk mengukur kekuatan relatif seseorang untuk melakukan perilaku.

Mahmudi (2010:20) menyatakan faktor-faktor yang mempengaruhi kinerja karyawan dalam suatu organisasi antara lain faktor personal atau individu, faktor kepemimpinan, faktor tim, faktor sistem, dan faktor kontekstual (situasional). Dapat dikatakan bahwa teori ini berhubungan dengan kinerja individu dalam melaksanakan suatu kegiatan. Begitu pula yang dikatakan oleh G. Douglas et al. (2008) menyatakan bahwa TRA telah digunakan untuk memprediksi suatu perilaku dalam banyak hal.

Sistem kelompok dari dua atau lebih komponen atau subsistem yang saling berhubungan yang berfungsi dengan tujuan yang sama (Hall, 2009:6). Menurut 
Mulyadi (2001:3) sistem adalah sekelompok unsur yang erat hubungannya dengan unsur yang lain yang berfungsi bersama-sama untuk mencapai tujuan tertentu.

Menurut Mulyadi (2001:7), suatu sistem pada dasarnya adalah sekelompok unsur yang erat berhubungan satu dengan lainnya, yang berfungsi bersama-sama untuk tujuan tertentu. Dari beberapa definisi diatas, maka dapat disimpulkan bahwa sistem terdiri dari beberapa komponen yang terkait satu sama lain dan tidak dapat berdiri sendiri.

Menurut Husein (2002:9), informasi adalah data yang telah diolah menjadi suatu bentuk yang mempunyai arti dan bermanfaat bagi manusia. Data adalah aliran fakta-fakta mentah yang menunjukkan peristiwa yang terjadi dalam organisasi dan lingkungan fisik sebelum diorganisir dan ditata menjadi suatu bentuk yang bisa dipahami dan digunakan. Informasi juga dapat didefinisikan sebagai data yang berguna yang diolah sehingga dapat dijadikan dasar untuk mengambil keputusan yang tepat (Bodnar dan Hopwood, 2001:1). Menurut Bodnar dan Hopwood (2001:1), informasi adalah data yang berguna yang diolah sehingga dapat dijadikan dasar untuk pengambilan keputusan.

Kumpulan sumber daya, seperti manusia dan peralatan, yang dirancang untuk merubah data ekonomi menjadi informasi yang berguna. Informasi ini kemudian dikomunikasikan kepada beragam pengambilan keputusan (Bodnan dan Hopwood, 2001:1). Menurut Geert et al. (2004), menyatakan bahwa sistem informasi akuntansi adalah suatu komponen yang mengumpulkan, menggolongkan, mengolah, menganalisa dan mengkombinasikan informasi keuangan yang relevan untuk pengambilan keputusan pihak-pihak luar (seperti 
Putu Dhana Belawa dan I Made Pande Dwiana Putra. Pengaruh ...

inspektorat pajak, investor, dan kreditor) pihak-pihak dalam (terutama manajemen).

Menurut Rivai (2006:384), insentif merupakan alat untuk memotivasi pekerja guna mencapai tujuan organisasi. Menurut Ardana dkk. (2012:67), insentif merupakan suatu bentuk motivasi yang dinyatakan dalam bentuk uang. Menurut Simamora (2007:445) insentif adalah tambahan kompensasi di atas atau di luar gaji atau upah yang diberikan oleh organisasi. Program insentif terdiri dari insentif individu dan kelompok. Berdasarkan beberapa uraian tersebut dapat disimpulkan bahwa insentif adalah bentuk motivasi yang dinyatakan dalam bentuk uang guna mencapai tujuan organisasi yang dikaitkan dengan kinerja dan gainsharing sebagai pembagian keuntungan bagi karyawan akibat peningkatan produktivitas atau penghematan biaya. Adapun jenis - jenis insensif-insentif material yang dapat diberikan dalam bentuk (Ika dan Vika, 2016): 1). Bonus, 2). Komisi, 3). Pembagian laba, 4). Kompensasi yang ditangguhkan, 5). Bantuan hari tua.

Tingkat pendidikan adalah tahapan pendidikan yang ditetapkan berdasarkan tingkat perkembangan seseorang, tujuan yang akan dicapai, dan kemampuan yang dikembangkan (Mangkuprawira, 2003:3). Menurut Diah dan Dharmadiaksa (2013) tingkat pendidikan dapat diasumsikan bahwa karyawan dengan tingkat pendidikan lebih tinggi akan menempati posisi lebih tinggi dalam organisasi dan memiliki akses yang lebih besar dalam pengambilan keputusan atas informasi yang tersedia. 
Pola pendidikan memberikan kemampuan kepada karyawan untuk (Ika dan Vika, 2016): 1). Menyesuaikan dan menyederhanakan situasi yang kompleks, 2). Menganalisa masalah untuk menentukan penyebab yang kritis dalam unit kerja, 3). Memilih tindakan yang terbaik untuk memecahkan masalah, 4). Mengantisipasi masalah-masalah sehingga mereka dapat mencegah terjadinya masalah berikutnya.

Pelatihan kerja merupakan sebuah proses mengajarkan pengetahuan dan keahlian tertentu serta sikap, agar karyawan semakin terampil dan mampu melaksanakan tanggung jawabnya dengan semakin baik serta sesuai dengan standar (Mangkuprawira, 2003:135). Pelatihan kerja dilakukan bertujuan untuk meningkatkan kemampuan karyawan dalam memberikan kontribusi pada efektivitas organisasi. Training (pelatihan) sumber daya manusia (SDM) sendiri dibagi menjadi lima jenis pelatihan antara lain (Ika dan Vika, 2016): 1).Skill Training, 2). Retraining, 3). Cross Functional Training, 4). Creativity Training, 5). Team training

Pelatihan sangat diperlukan bagi suatu perusahaan kerena bermanfaat bagi perusahaan dan individu. Adapun manfaat bagi perusahaan (Mangkuprawira, 2003:136), yaitu: 1). Memperbaiki pengetahuan dan keterampilan pada semua tingkat perusahaan, 2). Membantu meningkatkan citra perusahaan yang lebih baik, 3). Membantu pengembangan perusahaan, 4). Membantu dalam memahami dan melaksanakan kebijakan perusahaan, 5). Menyediakan informasi untuk kebutuhan masa depan dalam semua segi di perusahaan, 6). Perusahaan mendapat keputusan yang lebih efektif dalam pemecahan masalah, 7). Membantu dalam meningkatkan 
produktivitas dan kualitas kerja, 8). Membantu dalam mengatasi konflik dan juga mencegah stress dan tensi, 9). Memperbaiki hubungan pekerja dan manajemen, 10). Memperbaiki moral pekerja, 11). Membantu karyawan dalam menyesuaikan diri dengan perubahan yang ada.

Pengalaman merupakan suatu proses pembelajaran dan pertambahan perkembangan potensi bertingkah laku baik dari pendidikan formal maupun non formal atau biasa diartikan sebagai suatu proses yang membawa seseorang kepada suatu pola tingkah laku yang lebih tinggi. Bonner dan Walker (1994) mengatakan bahwa, peningkatan pengetahuan yang muncul dari pelatihan formal sama bagusnya dengan yang didapat dari pengalaman khusus. Ada beberapa indikator yang mempengaruhi pengalaman kerja antara lain (Ika dan Vika, 2016): 1). Waktu, 2). Frekuensi, 3). Jenis tugas, 4). Penerapan, 5). Hasil.

Menurut Rivai (2006:25) kinerja adalah gambaran mengenai tingkat pencapaian pelaksanaan suatu kegiatan dalam mewujudkan sasaran, tujuan, misi dan visi organisasi yang tertuang dalam strategic planning suatu organiasi. Menurut Handoko (2007:78) mengatakan bahwa, Penilaian kinerja adalah penentuan secara periodik efektivitas operasional suatu organisasi, bagian organisasi, dan karyawannya berdasarkan sasaran, standar dan kriteria yang ditetapkan sebelumnya. Fokusnya adalah untuk mengetahui seberapa produktif seorang karyawan dan apakah ia bisa bekerja sama atau lebih efektif pada masa yang akan datang sehingga karyawan, organisasi dan masyarakat semuanya memperoleh manfaat. 
Kinerja yang lebih baik akan tercapai jika individu dapat memenuhi kebutuhan individual dalam melaksanakan dan menyelesaikan tugas-tugas Goodhue, dkk (1995) dalam Tjhai (2003:8). Delone, dkk (1992) dalam Tjhai (2003:8) menyatakan baik pemanfaatan maupun sikap pemakai mengenai teknologi akan mempengaruhi kinerja individual dengan menjelaskan faktor kecocokan tugas dengan teknologi yang menguraikan bagaimana teknologi informasi mempengaruhi kinerja. Disamping itu Goodhue, dkk (1995) dalam Tjhai (2003:8) juga mengemukakan bahwa agar suatu teknologi informasi dapat memberikan dampak yang positif terhadap kinerja individual maka teknologi tersebut harus dimanfaatkan dengan tepat dan harus mempunyai kecocokan dengan tugas yang didukung.

\section{METODE PENELITIAN}

Penelitian ini dilaksanakan pada Disperindag Kota Denpasar yang beralamat di Gedung Sewaka Dharma lantai III Jl. Majapahit No. 1 Lumintang Denpasar. Pemilihan lokasi penelitian ini dikarenakan Disperindag Kota Denpasar merupakan instansi pemerintahan yang mengelola perindustrian dan perdagangan Kota Denpasar yang dalam kegiatan operasionalnya sudah menggunakan SIA. Objek dari penelitian ini adalah insentif, tingkat pendidikan, pelatihan, pengalaman kerja dan inerja individu pengguna sistem informasi akuntansi di Disperindag Kota Denpasar.

Variabel terikat dalam penelitian ini adalah kinerja individu pengguna sistem informasi akuntansi merupakan hasil kerja secara kualitas dan kuantitas yang dicapai oleh seseorang pegawai dalam melaksanakan tugasnya sesuai dengan 
tanggung jawab yang diberikan kepadanya. Indikator kinerja menurut Diah dan Dharmadiaksa (2013).

Variabel bebas dalam penelitian ini adalah insentif $\left(\mathrm{X}_{1}\right)$ merupakan sarana motivasi yang mendorong para pegawai pengguna sistem informasi akuntansi di Disperindag Pemerintah Kota Denpasar untuk bekerja dengan kemampuan yang optimal, yang dimaksudkan sebagai pendapatan ekstra di luar gaji atau upah yang telah di tentukan, tingkat pendidikan $\left(\mathrm{X}_{2}\right)$ merupakan faktor teknis yang berpengaruh terhadap kinerja individu pengguna sistem informasi akuntansi karena pendidikan merupakan upaya pembinaan dan kegiatan untuk mengembangkan sumber daya manusia dalam sikap, perilaku, keterampilan dan pengetahuan yang dimiliki sehingga dapat mendorong berkembangnya kemampuan-kemampuan dasar untuk meningkatkan penguasaan teori dan keterampilan, pelatihan $\left(\mathrm{X}_{3}\right)$ merupakan Pelatihan adalah serangkaian aktivitas yang dirancang untuk meningkatkan keahlian-keahlian, pengetahuan, pengalaman ataupun perubahan sikap individu, pengalaman kerja $\left(\mathrm{X}_{4}\right)$ merupakan Pengalaman kerja adalah proses pembentukan pengetahuan atau keterampilan tentang metode suatu pekerjaan karena keterlibatan karyawan tersebut dalam pelaksanaan tugas pekerjaan.

Sumber data yang digunakan dalam penelitian ini adalah data primer dan data sekunder. Data primer adalah data yang diperoleh secara langsung dari responden penelitian seperti kuesioner dan wawancara, data yang didapatkan berupa jawaban responden melalui penyebaran kuesioner terhadap 60 orang karyawan di Disperindag Kota Denpasar. Data sekunder yang dimaksud dalam 
penelitian ini adalah struktur organisasi serta daftar karyawan pengguna sistem informasi akuntansi di Disperindag Kota Denpasar.

Teknik analisis yang digunakan dalam penelitian ini adalah regresi linear berganda. Teknik analisis regresi linear berganda digunakan untuk mengetahui pengaruh insentif, tingkat pendidikan, pelatihan dan pengalaman kerja pada kinerja individu penggunaan sistem informasi akuntansi di Disperindag Kota Denpasar. Dimana variabel bebasnya adalah insentif, tingkat pendidikan, pelatihan dan pengalaman kerja, sedangkan variabel terikatnya adalah kinerja individu penggunaan sistem informasi akuntansi. Model regresi linear berganda dirumuskan sebaai berikut.

$Y=\alpha+\beta_{1} X_{1}+\beta_{2} X_{2}+\beta_{3} X_{3}+\beta_{4} X_{4}+\varepsilon$

Keterangan

Y

$\alpha$

$\beta_{1,}, \beta_{2}, \beta_{3}, \beta_{4}$

$=$ Kinerja individu pengguna sistem informasi akuntansi

$\mathrm{X}_{1}$

$=$ Konstanta

$=$ Koefisien regresi.

$\mathrm{X}_{2}$

$=$ Insentif

$\mathrm{X}_{3}$

$=$ Tingkat Pendidikan

$\mathrm{X}_{4}$

$=$ Pelatihan

$=$ Pengalaman

$\varepsilon$

$=$ Faktor pengganggu

\section{HASIL DAN PEMBAHASAN}

Analisis regresi linear berganda adalah analisis yang digunakan untuk mengetahui pengaruh variabel insentif $\left(\mathrm{X}_{1}\right)$, Tingkat Pendidikan $\left(\mathrm{X}_{2}\right)$, pelatihan $\left(\mathrm{X}_{3}\right)$, pengalaman kerja $\left(\mathrm{X}_{4}\right)$, tehadap kinerja individu pengguna sistem informasi akuntansi (Y) dengan menggunakan SPSS. 
Tabel 1.

Karakteristik Responden Berdasarkan Jenis Kelamin

\begin{tabular}{ccc}
\hline Jenis Kelamin & Jumlah (Orang) & Persentase (\%) \\
\hline Laki-Laki & 42 & 70 \\
Perempuan & 18 & 30 \\
Total & $\mathbf{6 0}$ & $\mathbf{1 0 0}$
\end{tabular}

Sumber: Data Primer Diolah, 2017 (Lampiran 1)

Tabel 1 menunjukan proporsi berdasarkan jenis kelamin dalam mengukur kinerja individu pengguna sistem informasi akuntansi di Disperindag Kota Denpasar yang didominasi adalah laki-laki sebesar 42 orang atau 70 persen dan berdasarkan jenis kelamin perempuan sebanyak 18 orang responden 30 persen. Ini menunjukkan sebagian besar individu pengguna sistem informasi akuntansi di Disperindag Kota Denpasar didominasi oleh laki-laki.

Tabel 2.

Karakteristik Responden Berdasarkan Pendidikan

\begin{tabular}{ccc}
\hline Pendidikan Terakhir & Jumlah (Orang) & Persentase (\%) \\
\hline Diploma 3 (D.3) & 3 & 5 \\
Sarjana (S.1) & 44 & 73 \\
S.2 & 13 & 22 \\
Total & $\mathbf{6 0}$ & $\mathbf{1 0 0}$ \\
\hline
\end{tabular}

Sumber: Data Primer Diolah, 2017 (Lampiran 1)

Tabel 2 berfungsi untuk mengetahui tingkat pendidikan yang dimiliki responden dalam mengukur kinerja individu pengguna sistem informasi akuntansi di Disperindag Kota Denpasar. Tabel 2 menunjukkan paling banyak responden memiliki tingkat pendidikan S.1 sebanyak 44 orang atau 73 persen, sedangkan paling sedikit responden yang memiliki tingkat pendidikan Diploma 3 (D.3) sebanyak 3 orang atau 5 persen. Hal ini menunjukkan rata-rata tingkat pendidikan pengguna sistem informasi akuntansi di Disperindag Kota Denpasar benar-benar membutuhkan tenaga kerja yang memiliki skill, pendidikan dan keahlian 
dibidangnya karena sudah dianggap sangat memahami sistem informasi akuntansi dalam pelaksanaan tugasnya.

Tabel 3.

Karakteristik Responden Berdasarkan Lama Bekerja

\begin{tabular}{ccc}
\hline Jenis Pekerjaan & Jumlah (Orang) & Persentase (\%) \\
\hline Kurang dari 5 tahun & 21 & 35 \\
5 s/d 10 tahun & 39 & 65 \\
Total & $\mathbf{6 0}$ & $\mathbf{1 0 0}$
\end{tabular}

Sumber: Data Primer Diolah, 2017 (Lampiran 1)

Tabel 3 berfungsi untuk mengetahui lama bekerja responden dalam mengukur kinerja individu pengguna sistem informasi akuntansi di Disperindag Kota Denpasar. Dapat dilihat persentase responden yang bekerja kurang dari 5 tahun sebanyak 21 orang atau 35 persen. Sudah bekerja 5 s/d 10 tahun sebanyak 39 orang atau 65 persen. Berdasarkan data pada Tabel 2 bisa kita lihat seluruh responden berdasarkan lama bekerja sudah memenuhi syarat sebagai pengguna sistem informasi akuntansi di Disperindag Kota Denpasar.

Tabel 4.

Kriteria dan Kategori Penilaian Jawaban kuisioner

\begin{tabular}{cc}
\hline Batas-batas Klasifikasi (Kriteria) & Kategori Penilaian \\
\hline $1,00-1,80$ & Sangat tidak baik \\
$1,81-2,60$ & Tidak baik \\
$2,61-3,40$ & Kurang baik \\
$3,41-4,20$ & Baik \\
$4,21-5,00$ & Sangat baik \\
\hline
\end{tabular}

Sumber : Ferdinand, 2006

Berdasarkan Tabel 4 dapat dilihat bahwa penilaian jawaban kuisioner terhadap pengaruh insentif, tingkat pendidikan, pelatihan dan pengalaman kerja pada kinerja individu pengguna sistem informasi akuntansi di Disperindag Kota Denpasar diukur dengan menggunakan lima batas-batas klasifikasi. Hasil statistik deskriptif dapat dilihat pada Tabel 5. 
Tabel 5.

Hasil Statistik Deskriptif

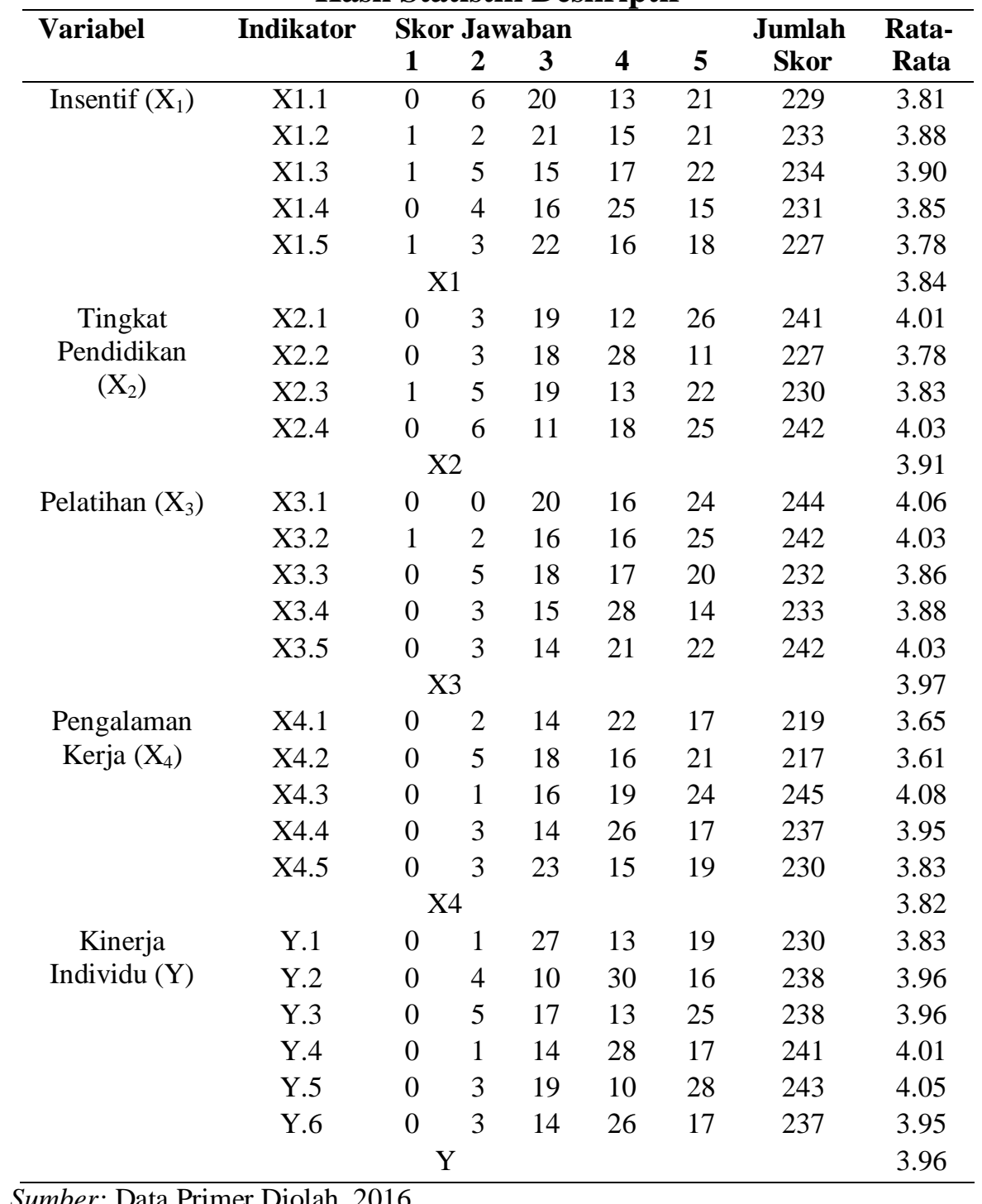

Berdasarkan Tabel 5 dapat dilihat bahwa variabel insentif $\left(\mathrm{X}_{1}\right)$ memiliki nilai jumlah skor rata-rata sebesar 3,84 (baik) dengan menggunakan lima skala likert. Nilai rata-rata terendah adalah indikator X1.5 sebesar 3,78 dan nilai ratarata tertinggi adalah indikator X1.3 sebesar 3,90.

Variabel tingkat pendidikan $\left(\mathrm{X}_{2}\right)$ memiliki nilai jumlah skor rata-rata sebesar 3,91 (baik) dengan menggunakan lima skala likert. Nilai rata-rata terendah adalah indikator X2.2 sebesar 3,78 dan nilai rata-rata tertinggi adalah 
indikator X2.4 sebesar 4,03. Variabel pelatihan $\left(\mathrm{X}_{3}\right)$ memiliki nilai jumlah skor rata-rata sebesar 3,97 (baik) dengan menggunakan lima skala likert. Nilai rata-rata terendah adalah indikator X3.3 sebesar 3,86 dan nilai rata-rata tertinggi adalah indikator X3.1 sebesar 4,06.

Variabel pengalaman kerja $\left(\mathrm{X}_{4}\right)$ memiliki nilai jumlah skor rata-rata sebesar 3,82 (baik) dengan menggunakan lima skala likert. Nilai rata-rata terendah adalah indikator X4.2 sebesar 3,61 dan nilai rata-rata tertinggi adalah indikator X4.3 sebesar 4,08. Variabel kinerja individu (Y) memiliki nilai jumlah skor rata-rata sebesar 3,96 (baik) dengan menggunakan lima skala likert. Nilai rata-rata terendah adalah indikator Y.1 sebesar 3,83 dan nilai rata-rata tertinggi adalah indikator Y.5 sebesar 4,05.

Tabel 6. Hasil Uji Validitas

\begin{tabular}{ccccc}
\hline No & Variabel & Instrumen & Pearson Correlation & Keterangan \\
\hline \multirow{4}{*}{1} & $\mathrm{Y}_{1}$ & 0,698 & Valid \\
& Kinerja Individu & $\mathrm{Y}_{2}$ & 0,669 & Valid \\
& $(\mathrm{Y})$ & $\mathrm{Y}_{3}$ & 0,655 & Valid \\
& $\mathrm{Y}_{4}$ & 0,753 & Valid \\
& & $\mathrm{Y}_{5}$ & 0,735 & Valid \\
& & $\mathrm{Y}_{6}$ & 0,836 & Valid \\
& & $\mathrm{X}_{1.1}$ & 0,781 & Valid \\
& & $\mathrm{X}_{1.2}$ & 0,579 & Valid \\
& Insentif $\left(\mathrm{X}_{1}\right)$ & $\mathrm{X}_{1.3}$ & 0,679 & Valid \\
& & $\mathrm{X}_{1.4}$ & 0,622 & Valid \\
& & $\mathrm{X}_{1.5}$ & 0,708 & Valid \\
& & $\mathrm{X}_{2.1}$ & 0,833 & Valid \\
& & $\mathrm{X}_{2.2}$ & 0,681 & Valid \\
& & $\mathrm{X}_{2.3}$ & 0,765 & Valid \\
& & $\mathrm{X}_{2.4}$ & 0,691 & Valid \\
\hline
\end{tabular}




\begin{tabular}{|c|c|c|c|c|}
\hline \multirow{5}{*}{4} & \multirow{5}{*}{ Pelatihan $\left(\mathrm{X}_{3}\right)$} & $\mathrm{X}_{3.1}$ & 0,700 & Valid \\
\hline & & $\mathrm{X}_{3.2}$ & 0,623 & Valid \\
\hline & & $\mathrm{X}_{3.3}$ & 0,653 & Valid \\
\hline & & $\mathrm{X}_{3.4}$ & 0,774 & Valid \\
\hline & & $\mathrm{X}_{3.5}$ & 0,713 & Valid \\
\hline \multirow{5}{*}{5} & \multirow{5}{*}{$\begin{array}{l}\text { Pengalaman Kerja } \\
\qquad\left(\mathrm{X}_{4}\right)\end{array}$} & $\mathrm{X}_{4.1}$ & 0,703 & Valid \\
\hline & & $\mathrm{X}_{4.2}$ & 0,601 & Valid \\
\hline & & $\mathrm{X}_{4.3}$ & 0,783 & Valid \\
\hline & & $\mathrm{X}_{4.4}$ & 0,540 & Valid \\
\hline & & $\mathrm{X}_{4.5}$ & 0,755 & Valid \\
\hline
\end{tabular}

Sumber: Data Primer Diolah, 2017

Tabel 6 menunjukkan bahwa masih-masing indikator variabel memiliki nilai pearson correlation lebih besar dari 0,30, maka ini berarti indikator/pertanyaan yang digunakan layak digunakan untuk mengukur apa yang seharusnya diukur, dan dapat mengungkap data dari variabel yang diteliti secara tepat.

Tabel 7.

Hasil Uji Reliabilitas

\begin{tabular}{lcc}
\hline \multicolumn{1}{c}{ Variabel } & Cronbach's Alpha & Keterangan \\
\hline Kinerja Individu $(\mathrm{Y})$ & 0,739 & Reliabel \\
Insentif $\left(\mathrm{X}_{1}\right)$ & 0,698 & Reliabel \\
Tingkat Pendidikan $\left(\mathrm{X}_{2}\right)$ & 0,719 & Reliabel \\
Pelatihan $\left(\mathrm{X}_{3}\right)$ & 0,716 & Reliabel \\
Pengalaman Kerja $\left(\mathrm{X}_{4}\right)$ & 0,705 & Reliabel \\
\hline
\end{tabular}

Sumber: Data Primer Diolah, 2017

Berdasarkan Tabel 7 dapat dilihat bahwa nilai alpha di hitung masingmasing variabel lebih besar dari $\mathrm{R}$ alpha tabel yaitu 0,60 sehingga dapat disimpulkan bahwa pernyataan dalam kuesioner tersebut reliabel. 
Tabel 8.

Hasil Uji Heteroskedastisitas

\begin{tabular}{lcl}
\hline \multicolumn{1}{c}{ Variabel } & Sig. & Keterangan \\
\hline Insentif $\left(\mathrm{X}_{1}\right)$ & 0,613 & Bebas heteroskedastisitas. \\
Tingkat Pendidikan $\left(\mathrm{X}_{2}\right)$ & 0,252 & Bebas heteroskedastisitas. \\
Pelatihan $\left(\mathrm{X}_{3}\right)$ & 0,434 & Bebas heteroskedastisitas. \\
Pengalaman Kerja $\left(\mathrm{X}_{4}\right)$ & 0,215 & Bebas heteroskedastisitas. \\
\hline
\end{tabular}

Sumber: Data Primer Diolah, 2017

Berdasarkan Tabel 8 dapat dilihat bahwa nilai sig. masing-masing variabel lebih besar dari 0,05 yang berarti variabel tersebut bebas heteroskedastisitas.

Tabel 9.

Hasil Uji Multikolinearitas

\begin{tabular}{lccl}
\hline \multicolumn{1}{c}{ Variabel } & Tolerance & VIF & Keterangan \\
\hline Insentif $\left(\mathrm{X}_{1}\right)$ & 0,259 & 3,864 & Bebas multikolinearitas. \\
Tingkat Pendidikan $\left(\mathrm{X}_{2}\right)$ & 0,379 & 2,636 & Bebas multikolinearitas. \\
Pelatihan $\left(\mathrm{X}_{3}\right)$ & 0,271 & 3,686 & Bebas multikolinearitas. \\
Pengalaman Kerja $\left(\mathrm{X}_{4}\right)$ & 0,268 & 3,750 & Bebas multikolinearitas. \\
\hline
\end{tabular}

Sumber: Data Primer Diolah, 2017

Berdasarkan Tabel 9 dapat dilihat bahwa nilai tolerence masing-masing variabel lebih besar dari 0,1 dan nilai VIF lebih kecil dari 10, sehingga dapat disimpulkan bahwa dalam model regresi tidak terjadi multikolinearitas dan dapat digunakan dalam penelitian.

Tabel 10.

Rangkuman Hasil Analisis Regresi Linear Berganda

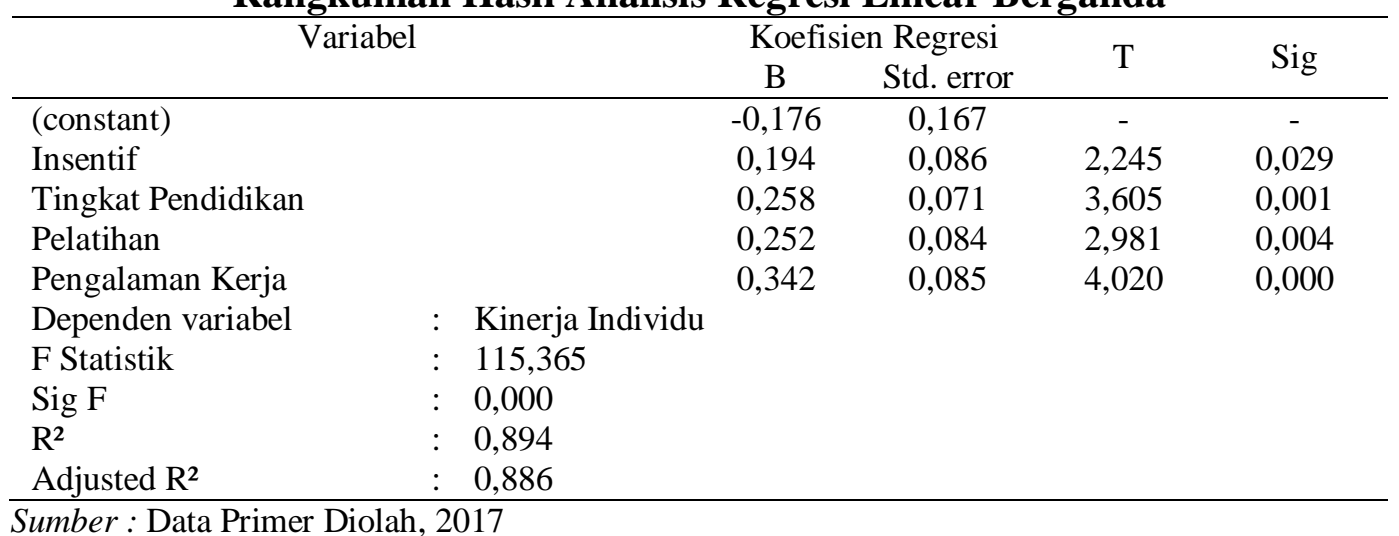

Berdasarkan Tabel 10, dapat dibuat persamaan regresi sebagai berikut. 


$$
Y=-0,176+0,194 X_{1}+0,258 X_{2}+0,252 X_{3}+0,342 X_{4}
$$

Berdasarkan persamaan di atas, dapat diuraikan nilai konstanta sebesar 0,176 menunjukkan bahwa bila nilai insentif $\left(X_{1}\right)$, tingkat pendidikan $\left(X_{2}\right)$, pelatihan $\left(\mathrm{X}_{3}\right)$, pengalaman kerja $\left(\mathrm{X}_{4}\right)$ sama dengan nol, maka nilai kinerja individu (Y) adalah sebesar $-0,176$ satuan. Nilai koefisien $\beta_{1}=0,194$ menunjukkan bila nilai insentif $\left(\mathrm{X}_{1}\right)$ bertambah 1 satuan, maka nilai dari kinerja individu (Y) akan mengalami peningkatan sebesar 0,194 satuan dengan asumsi variabel bebas lainnya konstan. Nilai koefisien $\beta_{2}=0,258$ menunjukkan bila nilai tingkat pendidikan $\left(\mathrm{X}_{2}\right)$ bertambah 1 satuan, maka nilai dari kinerja individu $(\mathrm{Y})$ akan mengalami peningkatan sebesar 0,258 satuan dengan asumsi variabel bebas lainnya konstan. Nilai koefisien $\beta_{3}=0,252$ menunjukkan bila nilai pelatihan $\left(\mathrm{X}_{3}\right)$ bertambah 1 satuan, maka nilai dari kinerja individu (Y) akan mengalami peningkatan sebesar 0,252 satuan dengan asumsi variabel bebas lainnya konstan. Nilai koefisien $\beta_{4}=0,342$ menunjukkan bila nilai pengalaman kerja $\left(\mathrm{X}_{4}\right)$ bertambah 1 satuan, maka nilai dari kinerja individu (Y) akan mengalami peningkatan sebesar 0,342 satuan dengan asumsi variabel bebas lainnya konstan.

Hasil uji $\mathrm{F}$ ( $F$ test) menunjukkan bahwa nilai $\mathrm{F}$ hitung sebesar 115,365 dengan signifikansi $\mathrm{F}$ atau $\mathrm{P}$ value 0,000 yang lebih kecil dari $\alpha=0,05$, ini berarti model yang digunakan pada penelitian ini adalah layak. Hasil ini memberikan makna bahwa ke empat variabel independen mampu memprediksi atau menjelaskan fenomena kinerja individu pengguna sistem informasi akuntansi di Disperindag Kota Denpasar. 
Pada Tabel 10 dapat dilihat bahwa besarnya Adjusted $\mathrm{R}^{2}$ adalah 0,886 atau 88,6 persen. Ini berarti variasi kinerja individu pengguna sistem informasi akuntansi di Disperindag Kota Denpasar dapat dijelaskan oleh variasi nilai insentif $\left(\mathrm{X}_{1}\right)$, tingkat pendidikan $\left(\mathrm{X}_{2}\right)$, pelatihan $\left(\mathrm{X}_{3}\right)$, pengalaman kerja $\left(\mathrm{X}_{4}\right)$ sebesar 88,6 persen, sedangkan sisanya sebesar 11,4 persen dijelaskan oleh faktorfaktor lain.

Pengaruh insentif terhadap kinerja individu pada Tabel 10 dapat dilihat bahwa nilai uji t untuk variabel insentif memiliki nilai sebesar 2,245 dengan tingkat signifikansi t pada uji satu sisi adalah 0,029/2 lebih kecil dari 0,05. Ini menunjukkan $\mathrm{H}_{1}$ diterima, yang berarti bahwa insentif berpengaruh positif pada kinerja individu pengguna sistem informasi akuntansi di Disperindag Kota Denpasar.

Pengaruh tingkat pendidikan terhadap kinerja individu pada Tabel 10 dapat dilihat bahwa nilai uji t untuk variabel tingkat pendidikan memiliki nilai sebesar 3,605 dengan tingkat signifikansi t pada uji satu sisi adalah 0,001/2 lebih kecil dari 0,05. Ini menunjukkan $\mathrm{H}_{2}$ diterima, yang berarti bahwa tingkat pendidikan berpengaruh positif pada kinerja individu pengguna sistem informasi akuntansi di Disperindag Kota Denpasar.

Pengaruh pelatihan terhadap kinerja individu pada Tabel 10 dapat dilihat bahwa nilai uji t untuk variabel pelatihan memiliki nilai sebesar 2,981 dengan tingkat signifikansi t pada uji satu sisi adalah 0,004/2 lebih kecil dari 0,05. Ini menunjukkan $\mathrm{H}_{3}$ diterima, yang berarti bahwa pelatihan berpengaruh positif pada 
Putu Dhana Belawa dan I Made Pande Dwiana Putra. Pengaruh ...

kinerja individu pengguna sistem informasi akuntansi di Disperindag Kota Denpasar.

Pengaruh pengalaman kerja terhadap kinerja individu pada Tabel 10 dapat dilihat bahwa nilai uji t untuk variabel pengalaman kerja memiliki nilai sebesar 4,020 dengan tingkat signifikansi t pada uji satu sisi adalah 0,000/2 lebih kecil dari 0,05 . Ini menunjukkan $\mathrm{H}_{4}$ diterima, yang berarti bahwa pengalaman kerja berpengaruh positif pada kinerja individu pengguna sistem informasi akuntansi di Disperindag Kota Denpasar.

\section{SIMPULAN}

Berdasarkan hasil analisis dan pembahasan yang telah dilakukan pada sebelumnya, maka dapat ditarik kesimpulan sebagai berikut: 1). Insentif berpengaruh positif signifikan terhadap kinerja individu pengguna sistem informasi akuntansi di Disperindag Kota Denpasar, hal ini dilihat dari nilai uji t untuk variabel insentif memiliki nilai sebesar 2,245 dengan tingkat signifikansi t pada uji satu sisi adalah 0,029/2 lebih kecil dari 0,05, 2). Tingkat pendidikan berpengaruh positif signifikan terhadap kinerja individu pengguna sistem informasi akuntansi di Disperindag Kota Denpasar, hal ini dilihat dari nilai uji t untuk variabel tingkat pendidikan memiliki nilai sebesar 3,605 dengan tingkat signifikansi t pada uji satu sisi adalah 0,001/2 lebih kecil dari 0,05, 3). Pelatihan berpengaruh positif signifikan terhadap kinerja individu pengguna sistem informasi akuntansi di Disperindag Kota Denpasar, hal ini dilihat dari nilai uji t untuk variabel pelatihan memiliki nilai sebesar 2,981 dengan tingkat signifikansi t pada uji satu sisi adalah 0,004/2 lebih kecil dari 0,05, 4). Pengalaman kerja 
berpengaruh positif signifikan terhadap kinerja individu pengguna sistem informasi akuntansi di Disperindag Kota Denpasar, hal ini dilihat dari nilai uji t untuk variabel pengalaman kerja memiliki nilai sebesar 4,020 dengan tingkat signifikansi t pada uji satu sisi adalah 0,000/2 lebih kecil dari 0,05.

Berdasarkan hasi penelitian dan simpulan maka saran yang dapat disampaikan adalah sebagai berikut: 1). Bagi Disperindag Kota Denpasar untuk menerapkan sistem pemberian insentif dalam meningkatkan kinerja individu. Insentif mempunyai fungsi untuk memotivasi pekerja guna mencapai tujuan organisasi, dengan menghubungkan kompensasi dengan pencapaian kinerja perusahaan seperti pembagian laba perusahaan yang adil bagi setiap pegawai sebagai pendorong untuk meningkatkan kinerja individu, 2). Disperindag Kota Denpasar diharapkan memperhatikan tingkat pendidikan setiap individu dalam pengguna sistem informasi akuntansi. Pendidikan mempunyai fungsi untuk meningkatkan kualifikasi tenaga kerja agar dapat lebih produktif sehingga mampu mengantisipasi masalah-masalah, mencegah terjadinya masalah serta mengambil tindakan yang terbaik untuk memecahkan masalah yang ada, 3). Pelatihan di Disperindag Kota Denpasar harus ditingkatkan untuk melatih setiap individu dalam pengguna sistem informasi akuntansi, dipastikan pelatihan keterampilan seperti cross training fungsional dalam pelatihan, kreativitas pelatihan serta menyediakan pelatihan team training untuk menyatukan visi dan misi dalam mencapai tujuan perusahaan, 4). Pengalaman kerja menjadi kunci bagi setiap individu dalam pengguna sistem informasi akuntansi, sehingga perlunya Disperindag Kota Denpasar menilai pengalaman dari segi penyelesaikan 
pekerjaan, menerima frekuensi pekerjaan sehingga pegawai menerima jenis tugas sesuai dengan pengalaman yang akan memberikan hasil pekerjaan yang maksimal sesuai dengan pengalaman yang dimiliki individu.

\section{REFERENSI}

Abdol et al., 2013. The Influence if Information Technology on The Efficiency of The Accounting Information Systems in Iran Hotel industry. International Research Journal of Applied and Basic Sciences. 4 (8): 2408-241

Bonner, S. E., dan P. L. Walker. 1994. The Effects of Instruction and Experience on the Acquisition of Auditing Knowledge. The Accounting Review. 1(1): 157-178

Brigitte Eierle and Wolfgang Schultze, 2013. The Role of Management As A User of Accounting Information: Implications for Standard Setting. Journal Accounting and Management Information Systems. 12(2): 155 -189

Catherine Equey Balzli and Bernard Morard, 2012. The Impact of an Integrated Financial System Implemantation on Acounting Profiles in a Public Administration: An Ethnographic Approach. Journal of Accounting and Organizational Chage. 4(1): 1-20

David et al., 2012. The Effects of Incentive System and Cognitive Orientation on Teams' Performance. Journal American Accounting Association. 24(2): $177-191$

Davis, Fred D., Viswanath Venkatesh. 2000. A Critical Assesment of Potential Measurement Biases in The Technology Acceptance Model : Three Experiments. International Journal of Human Computer Studies, 45.

F Red D., and D. Avis, 2006. A Critical Assessment of Potential Measurement Biases in The Technology Acceptance Model : Three Experiments. International Journal Human-Computer Studies. 4(5): 19 - 45

Gorda, I Gst Ngr. 2006. Management Sumber Daya Manusia. Astabrata: Denpasar

Hall, James A. 2009. Sistem Informasi Akuntansi. Edisi 4.Jakarta : Salemba Empat

Handoko, T.Hani. 2007. Manajemen. Edisi kedua : BPFE. Yogyakarta. 
Husein, Muhammad Fakhri dan Amir Wibowo. 2002. Sistem Informasi Manajemen. UPP AMPYPKN. Yogyakarta.

Jaluanto dan Nerile Hirda Yuhanni, 2014. Pemanfaatan Sistem Merit pada Pengembangan Sistem Informasi Akuntansi Penggajian (Studi Kasus pada PT Murba Jaya Abadi Semarang). Jurnal Ilmiah UNTAG Semarang. 1(4): $15-29$

Krisnawati, Luh Ayu. 2009. Pengaruh Gender, Jabatan, Usia, Pengalaman, Kompleksitas Tugas dan Tingkat Pendidikan Terhadap Efektivitas Sistem Informasi Akuntansi pada PT. Asuransi Jiwa Bumi Asih Jaya Cabang Bali/Nusa Tenggara. Skripsi Sarjana Jurusan Akuntansi pada Fakultas Ekonomi Universitas Udayana.

Mahmudi, 2010. Manajemen Keuangan Daerah. Jakarta: Erlangga.

Mangkuprawira, Tb. Sjafari. 2003. Manajemen Sumber Daya Manusia Strategik. Jakarta. Ghaflia Indonesia.

McQueen, R.J. and Mills, A.M., 2008. End User Computing Sophistication in a Large Health Services Organization, Journal Resources Management Association Conference. 2(5): 263-276

Mulyadi. 2001. Sistem Akuntansi. Edisi ketiga. Salemba Empat. Jakarta.

Nomza Mndzebele, 2015. The Usage of Accounting Information Systems for Effective Internal Controls in the Hotels. International Journal of Advanced Computer Technology (IJACT). 2(5): 1-3

Notoatmodjo, S. 2009. Perilaku kesehatan dan ilmu perilaku, Jakarta: PT Rineka Cipta

Rivai, Veithzal. 2006. Kepemimpinan dan Perilaku Organisasi. Jakarta : PT. Raja Grapindo Persada

Rohida Utami Monats. 2016. Pengaruh Tingkat Pendidikan, Pengalaman Kerja, Insentif dan Komitmen Organisasi Terhadap Kinerja Pengelola Keuangan pada Satuan Kerja Perangkat Daerah (SKPD) Kabupaten Indragiri Hilir. Jurnal Fekon. 3(1): 749-762

Rosiana. 2010. Pengaruh Usia, Tingkat Pendidikan, Jabatan, Pengalaman, Kompleksitas Tugas dan Kompetensi Terhadap Efektivitas Sistem Informasi Akuntansi pada PT. Akses (PERSERO) di wilayah Bali. Skripsi Jurusan Akuntansi Fakultas Ekonomi Universitas Udayana. 
Simamora, Henry. 2007. Manajemen Sumber Daya Manusia. STIE-YKPN, Yogyakarta

Sarah E. Bonner, Geoffrey B. Sprinkle, 2002. The Effects of Monetary Incentives on Effort and Task Performance: Theories, Evidence, and a Framework for Research. Journal Accounting Organizations and Society. 2(7): 303-345

P. Patel, 2015. Effects of Accounting Information System on Organizational Profitability. International Journal of Research and Analytical Reviews. 2(1): $72-76$

Tiksnayana Vipraprastha dan Maria M.Ratna Sari, 2016. Pengaruh Pengalaman Kerja, Pelatihan, Tingkat Pendidikan dan Insentif Terhadap Efektivitas Penggunaan Sistem Informasi Akuntansi. Jurnal Akuntansi Universitas Udayana. 15(3): 1826-1855

Tjhai, Fung Jen. 2002. Faktor-faktor yang Mempengaruhi Kinerja Sistem Informasi Akuntansi. Jurnal Bisnis dan Akuntansi. 4 (2): 135-154.

Windha Fahmiswari.K. A.A Istri., Dharmadiaksa, Ida Bagus., 2013. Pengaruh Kinerja Individual Karyawan Terhadap Efektivitas Penggunaan Sistem Informasi Akuntansi. Jurnal Akuntansi Universitas Udayana. 5(3): 690706 